\title{
BEHAVIOURAL FACTOR-BASED CLUSTERING TO EXAMINE WHY SMALL BUSINESSES CHOOSE PARTICULAR BANK: THE NEW ZEALAND EVIDENCE
}

\author{
Zakaria Boulanouar ${ }^{*}$, Tahar Lazhar Ayed ${ }^{* *}$, Stuart Locke ${ }^{* * *}$ \\ * Corresponding author, Business Division, Higher Colleges of Technology, Dubai, United Arab Emirates \\ Contact details: Finance program, Business Division, Higher Colleges of Technology, P.O. 25026, Dubai, United Arab Emirates \\ ** Department of Marketing, College of Business, Umm Al Qura University, Mecca, Saudi Arabia \\ *** School of Accounting, Finance and Economics, Waikato Management School, University of Waikato, Hamilton, New Zealand
}

OPEN ACCESS

How to cite this paper:

Boulanouar, Z., Ayed, T. L., \&

Locke, T. (2019). Behavioural factor-

based clustering to examine why small businesses choose particular bank: The New Zealand evidence [Special issue]. Corporate Ownership \& Control, 17(1), 292-305.

http://doi.org/10.22495/cocvl7ilsiartl l

Copyright @ 2019 The Authors

This work is licensed under a Creative Commons Attribution 4.0 International License (CC BY 4.0).

https://creativecommons.org/licenses /by/4.0/

ISSN Online: 1810-3057

ISSN Print: 1727-9232

Received: 13.09.2019

Accepted: 25.12 .2019

JEL Classification: C3, G4, G2 DOI: $10.22495 /$ cocvl7ilsiartl1

\begin{abstract}
In this paper, using the theory of planned behaviour, behavioural and non-behavioural factors underpinning small business' (SB) choice of a bank are explored. To date, we are unaware of any study that uses a behavioural approach to study bank selection by SBs owner/managers. These factors, discussed in the literature, form the basis of a questionnaire administered in New Zealand. Univariate \& bivariate analyses, in addition to cluster analysis of the data, show that behavioral factors, such as knowing a person in the bank, prior personal banking experience and recommendation/referrals, are shown to be most important. Also, after controlling for size, industry, and age of business it is found that there is no statistically significant difference in choice variables. Further, inertia is strong once a bank is chosen and cost, while emphasized, does not trigger actions. A cluster analysis of SB owners/managers produced four different groups. However, all of these groups are affected by the same behavioural factors in their choice of a banking partner.
\end{abstract}

Keywords: SME, Bank Selection, Behavioural, TPB

Authors' individual contribution: Conceptualisation - Z.B. and S.L.; Methodology - Z.B., T.L.A., and S.L.; Formal Analysis - Z.B., T.L.A., and S.L.; Writing - Z.B., T.L.A., and S.L.

\section{INTRODUCTION}

It is generally well established that both economic and non-economic drives impact small business (SB) financial decision making (Gallo, Tàpies, \& Cappuyns, 2004; Moritz, Block, \& Heinz, 2016). Moreover, small businesses comport themselves differently from and use some finance-related instruments and techniques that are dissimilar to, those used by their larger counterparts (López-Gracia \& Sogorb-Mira, 2008; Berger \& Udell, 1995).

Yet, much research into SB finance-related decision making is still dominated by the traditional framework of analysis (Southey, 2011; Al Balushi, Locke, \& Boulanouar, 2018) using the economic theory of rational decision making as expressed by the expected utility theory (Schoemaker, 1982). This is despite the emergence of alternative explanations such as Prospect Theory (Kahneman \& Tversky,
1979), Image Theory (Beach, 1990), Mental Accounting (Thaler, 1999), the theory of reasoned action and the theory of planned behaviour (Ajzen, 1991).

Specifically, investigations into reasons underpinning small business choice of a business banking partner is an area of research which, to the best of our knowledge, has only used traditional, and non-behavioural, theoretical explanations (Ghosh, Ghosh, \& Khan, 2015; Nielsen, Terry, \& Trayler, 1998; Nielsen, Trayler, \& Brown, 1995; Pauluzzo \& Geretto, 2017).

It is true that the traditional finance paradigm has contributed greatly to our understanding of factors affecting bank selection decision-making (Kaur, 2015; Trayler, Nielson, \& Jones, 2000). However, from a managerial choice viewpoint, which includes nonfinancial and behavioural factors (Matthews, Vasudevan, Barton, \& Apana, 1994; Barton \& Gordon, 1988; Zellweger, Frey, \& 
Halter, 2005), the traditional financial theories fail to deal with the intricacies around financial decisionmaking in SBs. Furthermore, many of the recent studies show that: 1) traditional approaches either ignore managerial preferences or fail to account for the importance of SBs' preferences and norms (Pearson, Carr, \& Shaw, 2008; Al Balushi et al., 2018); 2) decision making in most SBs is impacted by the human behaviour, attitudes and nonfinancial goals of the SB owner/manager (Zellweger et al., 2005).

The above realisations constituted our primary motivation for using a noneconomic rationale to investigate bank choice decisions. Our current research answers the increasing calls to expand financial choice models to research financial decisions in SBs (Barton \& Gordon, 1987; Barton \& Gordon, 1988; Beattie, Goodacre, \& Thomson, 2006; Matthews et al., 1994; Al Balushi et al., 2018) and to explore how behavioural factors influence the choice of a business-banking partner by SBs.

In this research, we use Ajzen's (1991) theory of planned behaviour (TPB), which maintains that behavioural intention is defined as the subjective probability that a person will perform certain behaviour. According to the TPB (Ajzen, 1991), behavioural intention is represented as a function of three basic determinants - attitudes, subjective norm, and perceived control. Factors that affect these determinants affect behavioural intention and the more favourable the subjective norm and the attitude and the greater the perceived control, the stronger the person's intention to perform the behaviour (i.e., selecting a specific bank). Factors affecting behavioural intention and other factors extracted from prior research were used in a survey to obtain information from SBs proprietors in New Zealand on why they chose their bank. We used univariate, bivariate and cluster analysis to analyse the data.

The results show that the most important factors in choosing a bank were behavioural in nature including prior personal experience with the bank, personal contacts through knowing someone in the bank, and a recommendation from a friend or associate. Other findings included that although cost of banking was viewed by SBs as very important influence in their decision to switch banks, the fact that majority of those businesses do not move, coupled with the other finding that they don't evaluate bank costs in their initial bank choice decision point to a realisation that once associated with a bank, there is little interest in moving. These results are not in line with the predictions of rational/traditional theoretical explanations of why SBs chose a particular business banking partner. Instead, the overall conclusion points to SB owners/managers as being largely affected by behavioural factors in explaining their decision making about which bank to partner with.

Our research contributes to the SB finance literature in significant ways. Firstly, we expand the understanding of SBs' financial decision-making by acknowledging the unique SB owner-manager influences on financing decisions. Secondly, as previous studies on SB bank selection focused on non-behavioural factors, we obtain a more comprehensive perspective by including behavioural factors. Thirdly, we examine the factors that inform and influence attitudes towards bank selection from the SBs' Owner-managers' perspective and we consider these previously ignored perspectives using the ТPB as the framework of our investigation. Lastly, by showing that non-economic variables can influence financing behaviour decisions we add to the wider research literature on SBs and SB finance in particular.

The remainder of this paper is structured as follows: Section 2 reviews the literature, Section 3 presents the data, Section 4 presents and discusses the empirical results, and Section 5 concludes the paper.

\section{LITERATURE REVIEW}

Much of the early bank selection studies assume that SB managers behave rationally. This is despite other studies, such as those of Barton and Gordon $(1987,1988)$, showing that managerial choice and non-rational elements of decision-making are important features that need to be taken into consideration to understand financial decision-making in SBs. SME (small and mediumsized entreprise) behaviours are largely unique due to the specific properties these firms enjoy. For instance, because SMEs try to retain generational influence, their managerial succession influences their financing strategies, often qualified as conservative, and financial plans (López-Gracia \& Sánchez-Andújar, 2007). SME owners/managers also ward off external equity so as not to lose control over their business, even when such a strategy could affect their business profitability and growth opportunities (Michaelas, Chittenden, \& Poutziouris, 1998).

This evidence shows that financial choices vary among small business owner-managers (Moritz et al., 2016). This is because SBs are highly dependent on a single decision-maker, who is usually the ownermanager (Gibcus, Vermeulen, \& De Jong, 2006). Furthermore, studies have shown that SME owners self-select to run businesses that best match their own areas of expertise (Wiklund, Delmar, \& Sjöberg, 2005). Therefore SB financing behaviour might be the result of owner-managers' personal attitudes and these attitudes, therefore, become embedded into the SMEs (Michaelas et al., 1998). Furthermore, finance-related decisions of SMEs are quite complex because they depend on a number of financial, social and behavioural considerations (Romano, Tanewski, \& Smyrnios, 2001). It has been argued that SBs are likely to engage in a financial logic based on not only rational economic motivation but also behavioural and nonfinancial factors on which there is a paucity of research from finance researchers (Michaelas et al., 1998).

Consequently, to better understand the reasons underpinning SBs' choice of a bank we need to explore the traditional as well as the behavioural and nonfinancial factors (Baker \& Ricciardi, 2014; Matthews et al., 1994) such as the subjective norms, attitudes, and perceived behavioural control of the businesses' owner-managers. We begin by discussing the former, then move on to the latter. 


\subsection{Theory of planned behaviour and small business financing}

In this study, we use elements of Ajzen's (1991) TPB to study bank selection behaviour in SMEs. TPB explains and predicts human behaviour, which is behaviour not entirely under the person's self-control and where behavioural decisions and the proximate behaviour are seen as determined primarily by the decision-maker's behavioural intentions (Ajzen, 2002). These behavioural intentions, in turn, are determined by three determining factors. These factors are: 1) attitudes defined as (un)favourable evaluations of the likely attributes or consequences of a behaviour; 2) perceived norms, which refer to the beliefs of the decision-maker about the significant others' expectations, such as family, friends and advisors such as an accountant or mortgage broker, about whether to perform a behaviour or not; 3) perceived behavioural control denoting the perceived ease or difficulty to perform a behaviour depending on the belief of the decision-maker about the existence of behaviour-limiting factors.

In small businesses, the owner-manager is usually the single decision-maker about all aspects including financial decisions (López Salazar, Contreras Soto, \& Espinosa Mosqueda, 2012). The beliefs and values of this owner/manager are substantial drivers in strategy making tasks (Heck, 2004). Our model showing these and other nonbehavioural factors affecting bank selection is exhibited in Figure 1, below.

\subsubsection{Attitudes}

Although very important, research on bank selection often neglects the SB owner's attitudes (Southey, 2011). The decision of the SB owner/manager to select a specific bank is not solely fashioned by rational reasons. Rather, it is shaped as much by the owner/manager's desires and wishes (Read, 2002) as by any restrictions imposed by potential banking partners. Desires and wishes are and can be informed by previous experiences. Therefore, attitudes are a factor affecting the behavioural intention of the SB owner/manager to select a specific banking partner.

Figure 1. Factors affecting bank selection

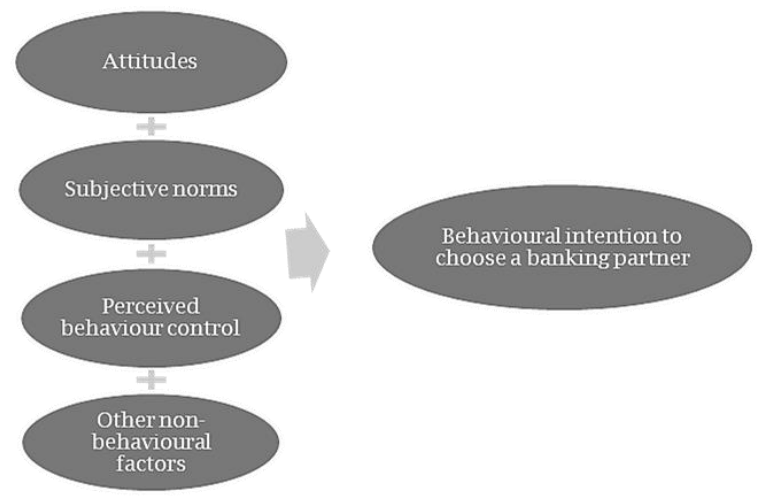

\subsubsection{Subjective norms}

Social norms have been shown to significantly affect SB owner/managers' decision-making (Chang, Memili, Chrisman, Kellermanns, \& Chua, 2009). For example, Anderson, Jack, and Dodd (2005) show that an important source of support and encouragement to entrepreneurs is family. In addition, Greve and Salaff (2003) illustrate how close contacts, such as family members, are used by entrepreneurs to help them during all stages of business decisions. This is consistent with practice as reported by Bank of America (2016), where the Head of SB, Bank of America, stated: "We know [SB] owners are inherent self-starters making significant personal sacrifices on behalf of their businesses, but what's fascinating is this dimension of family, friends and community that they see as core to their success" (p. 1).

Fishbein and Ajzen (1975) proposed subjective norms are a direct determinant of behavioural intention. This is because under significant social pressure and social influence, individuals would perform a not so favoured behaviour if they believed that one or more important referents think they should do so, and if they are sufficiently motivated to comply with the referents (Venkatesh \& Davis, 2000). Thus, if family or friends favour a specific bank, these norms should affect bank choice via behavioural intention.

\subsubsection{Perceived behavioural control (PBC)}

PBC indicates people's view of their ability to perform a given behaviour. According to East (1993), if people believe that they have control over an action they will be more confident of achieving the outcome(s) of that action. Our study defines PBC as the perception of the degree of control the decisionmaker has regarding the selection of a particular banking-partner. For example, fear of being rejected by a bank would discourage the SB owner/manager from approaching that specific bank. Ajzen (2002) claims that a high level of PBC should usually correspond to greater behavioural intention and increased efforts and perseverance to realise the intended behaviour.

Empirically, PBC has been shown to be one of the most influential factors that play an important role in enhancing performance in entrepreneurship and in determining financial decisions. Studies, such as of Taylor and Todd (1995), show that PBC explain significant variance in intention and subsequently in behaviour. It also shows that there is a positive association between $\mathrm{PBC}$ and intention, emphasising the importance of psychological traits such as $\mathrm{PBC}$, as maintained by Farrell, Fry, and Risse (2016), in explaining financial decision-making. However, research into the relationship between $\mathrm{PBC}$ and financial behaviour is limited (Farrell et al., 2016). Our study is a step towards filling this gap.

\subsection{Other factors}

Bank location, in much previous research, has been supported as an important factor in bank choice. Research suggests that business owners often choose a bank based on which branch is nearest their home or where they do their personal/business 
banking (The Economist, 2007). This is because SBs still make frequent use of bank branches.

Lucey (1990) notes that many small firms want a bank that is conveniently located. More recent research, cognisant of internet banking, finds that around $50 \%$ of SBs want to have a branch five minutes away rather than have free online services and no local branch. A 2006 survey of small businesses finds that although most banks are spending considerable money and time to promote their online service, SB owners believe having their bank nearby is the most important bank characteristic for conducting their firm's banking business. $62 \%$ of SBs use a local or regional bank as their primary bank because they want to be physically close for cash deposits, especially for retail enterprises (Scott \& Dunkelberg, 2006). In New Zealand $70 \%$ of businesses have zero employees (BusinessNZ, 2019) and, not surprisingly, businesses are not willing to spend valuable time waiting for services.

Regarding banking costs, the level of charges is not seen as a key factor in the choice of bank. Mazur (2007) states that SB owner/managers choose the bank according to the best products and interest rate, but the fact is these owners think there are no differences between these products, they are just the same service operated by different banks. Furthermore, a previous study in New Zealand by Locke and Boulanouar (2009), which investigated the cost of banking services to SBs, has shown that "the ability of individual small businesses to readily ascertain which bank will provide the required services at least cost is not a simple matter. The range of services is not necessarily directly comparable between banks and the bundling of charges does not lead to easy comparison" (p. 211212). The conclusion of Locke and Boulanouar (2009) was: "The lack of price competition in the provision of small business banking services combined with limited transparency concerning actual fee levels prevents small businesses from readily estimating likely fee levels" (p. 211).

The decision to switch banks has been the subject of a number of investigations. The genera consensus is that many SBs consider the possibility of changing banks but very few actually make a move. Howorth, Peel, and Wilson (2003) observe that much of the literature is anecdotal, impressionistic and based on the commonly held assumption of inertia rather than loyalty and belief it is important to stay with the same bank. In the UK, 34\% of SBs are reported as considering a swap of banks but only $4 \%$ actually did so according to the Federation of Small Businesses (1998). The Howorth et al. (2003) study notes dissatisfaction with service and the finance available are important factors in motivating thinking of changing banks. However, information capture is important and a distinguishing feature between those that swapped and those that didn't was the ability to convey information about their activities and thus attract favourable finance.

Heffernan (2006) uses an econometric model to examine the pricing behaviour of British financial institutions with respect to key bank products/services offered to small and mediumsized enterprises (SMEs) including current accounts, investment accounts, business loans, and mortgages. She concludes that policies directed at improving information and making it easier for small businesses to change banks/accounts would reduce inertia and improve competition among financial institutions. The inertia of SMEs with regard to changing banks was also noted by Carey and Flynn (2005). Their study shows a high degree of Irish SME dependence on banks as a source of funding and evidence of increases in bank rates/charges with limited switching between banks to avail of better rates. They conclude that the key contribution of their paper is that it highlights the need for Irish SMEs to proactively manage their potential funding sources.

With respect to bank marketing, television advertisements for business banking that were screened in New Zealand at the time when this research was underway, suggest there are prompts that attribute of banking other than the cost of services being promoted. This assertion is supported by previous research. For example, the findings of Mylonakis (2008) in Greece found that bank customers may not be interested in advertising in the first instance while choosing their bank, but this is the initial reaction of all those who are interested in achieving the most cost-beneficial and favorable terms. The point here is that advertising is not the main criterion in choosing a bank. However, its existence is a prerequisite, as it verifies a bank's critical presence in the market and plays an important role in the choices.

In New Zealand, there are four main banks operating a branch network. The same banks operate in Australia, with different names, and are the predominant players in that market. However, there are a number of smaller banks, which are actively involved in the SME market. The proposition here is that the factors influencing the choice of banks alter when there is a greater number of choices to be considered. Strachan and Weston (1998) suggest that SBs lending increases with the size of the banks. An empirical study, based on US data by Rauch and Hendrickson (2004), finds that consolidation of banks has led to larger interest rate gaps between SBs loans at small banks versus larger banks. This is evidence that consolidations are effectively increasing the cost of borrowing.

Mazur (2007) finds that where a SB already has a personal account with the bank, chances are good that they will also open a SB account with that same bank. Prior studies in New Zealand indicate that 70\% of businesses have a relationship of more than 4 years with the same bank, and $36 \%$ have a relationship of more than 10 years, indicating that SMEs are inclined to have longer-term relationships with their financing institutions according to Statistics New Zealand and the Ministry of Economic Development (2010). Research undertaken by the New Zealand Centre of SME Research in 2006, identified that $84 \%$ of those SME's in New Zealand interviewed preferred to have a personal relationship with their bank, commenting that awareness and knowledge of each other's businesses would result in reduced errors, reducing the need for repetition of details and explanations and increasing assurance overall (Perry, Cardow, Massey, $\&$ Tweed 2006). Howorth et al. (2003) addressing the information asymmetry issue suggests that it has been established that having a longstanding relationship with a bank leads to lower interest 
rates, lower collateral requirements and increased availability of finance. This, in turn, makes choosing to add the business banking account to the owners' personal bank an attractive option.

As Julian and Ramaseshan (1994) stated, delivering quality services and products to customers has a significant positive influence on the chances of success and survival in today's competitive banking environment. Lymperopoulos, Chaniotakis and Soureli (2006), examined the importance of service quality in bank selection and found bank service quality is the most important element that customers consider in order to select their mortgage providers and establish a long-term relationship with them

A number of studies have argued that the efficiency of banking services are the main selection criteria of a specific bank (e.g., Holstius \& Kayank, 1995; Yue \& Tom, 1995; Mylonakis, Malliaris, \& Siomkos, 1998; Coyle, 1999; Driscoll, 1999).

\section{DATA AND METHODOLOGY}

Following the recommendation of Fishbein and Ajzen (2010) concerning constructing TPB questionnaires, an instrument using a 5-point Likert scale was employed to collect the data for the research model's constructs. Behavioural and nonbehavioural questions, distilled from the literature, formed the basis of the questionnaire. There were sixteen questions in total, reducing the likelihood that potential respondents would be daunted by the length or complexity of the instrument. Questions 1 through to 4 inclusive were demographic in nature, providing useful input about the respondents permitting sub-sample analysis for example by the number of employees. The rest of the questions were based upon those issues raised in the literature as 'explanatory variables' for the small business choice of preferred bankers. A list of the 16 questions is presented in Appendix.

The initial survey utilised an online communication protocol established by the Chamber of Commerce in New Zealand. SBs received an email from the Chamber Chief Executive requesting that proprietors of businesses with 50 or fewer employees participate. A hyperlink in the email opened a web-based questionnaire and submission process. The system automatically recorded each response and compiled these in an Excel spreadsheet containing a separate worksheet for each of the 16 questions. The survey remained open for one week and 59 responses were received.

\section{ANALYSIS}

\subsection{Univariate and bivariate analysis}

Responses to each of the questions numbered 5 to16 provide useful insights into what the small businesses consider to be important components of the bank choice decision calculus. This initial univariate/bivariate analysis, when combined with the demographics solicited in questions 1 to 4 , provides further insights relating to size, time in business etc.

Question 5 addresses the issue of what is the most important influence on the small business choice of business banking partner. Overall results show the primacy of behavioural factors. The aggregate responses are shown in Table 1 (below). Overall, 43\% of businesses respond that their most important influence is prior to the personal banking experience. However, further analysis shows that more than $50 \%$ of micro-businesses (1-5 employees) chose this as their most important influence. As these businesses are very small, it is likely that the owners decided to continue with their current bank because of ease and experience. As businesses increase in size other, less personal, reasons started to be the most important influence. $68 \%$ of the respondents identify personal considerations of some sort as the most influential factor in their choice of a particular bank to be their business bank. The factor of most significant importance is prior experience with the bank, either as a personal customer or through the business owner's family having accounts with that particular bank. A friend or associate working within the bank or being recommended to a particular bank by a friend or associate is also significant. The small business owner's personal relationship with a bank and their various other personal, relationship-orientated considerations form the major overriding factor in the decision-making process when choosing a business banking partner.

Table 1. What is the most important influence on your choice of the business bank?

\begin{tabular}{|l|c|}
\hline Because my family used this bank & $5.26 \%$ \\
\hline Knowing someone who worked in the bank & $7.89 \%$ \\
\hline Other & $31.58 \%$ \\
\hline Somebody else recommended it to you & $11.84 \%$ \\
\hline Your prior personal banking experience & $43.42 \%$ \\
\hline Total & $100.00 \%$ \\
\hline
\end{tabular}

The personal relationship appears to be of paramount importance so exploration of where any recommendations may have come from is appropriate. Question 7 addresses this issue and the responses are tabulated in Table 2 (below).

Table 2. Who recommended this bank to you?

\begin{tabular}{|l|c|}
\hline Accountant & $8.0 \%$ \\
\hline Family/friend & $21.3 \%$ \\
\hline Mortgage broker & $6.7 \%$ \\
\hline Nobody & $37.3 \%$ \\
\hline Other & $26.7 \%$ \\
\hline
\end{tabular}

Table 3. Bank recommendation by business size

\begin{tabular}{|c|c|c|}
\hline Size & Recommended by & Percentage \\
\hline $1-5$ employees & Accountant & 5 \\
\hline & Family/friend & 15 \\
\hline & Insurance advisor & 3 \\
\hline & Mortgage broker & 8 \\
\hline & Nobody & 46 \\
\hline & Other & 23 \\
\hline $5-10$ employees & Family/friend & 38 \\
\hline & Mortgage broker & 6 \\
\hline & Nobody & 19 \\
\hline & Other & 38 \\
\hline $11-20$ employees & Accountant & 25 \\
\hline & Family/friend & 25 \\
\hline & Nobody & 25 \\
\hline & Other & 25 \\
\hline $21+$ employees & Accountant & 19 \\
\hline & Family/friend & 13 \\
\hline & Mortgage broker & 6 \\
\hline & Other & 25 \\
\hline
\end{tabular}


$37 \%$ of the businesses indicate that nobody recommended the bank to them. A significant majority of businesses are influenced by their choice of the bank through recommendations made to them. As shown in Table 3 (above), further investigation reveals that the smallest sized businesses are the least likely to have received recommendations. Potentially, the smaller businesses relied on their own prior personal banking experience as the basis for business banker choice. Notably, when the responses to questions 2 and 6 are cross-tabulated there is a discernible pattern.

The close linkage between personal and business financial arrangements faced by small businesses does not appear explicitly in the arrangement of mortgages. While personal assets are typically pledged as security by proprietors of smaller businesses when raising debt capital, especially bank loans, it is not apparent banks offering personal mortgages have required business banking to be transferred to them as part of the arrangements. As shown in Table 4 (below), only 25\% of businesses are required to bank with owners' personal mortgage providers.

Table 4. Is business banking a requirement for a mortgage?

\begin{tabular}{|l|c|}
\hline & Percentage \\
\hline Yes & $25.33 \%$ \\
\hline No & $74.67 \%$ \\
\hline Total & $100.00 \%$ \\
\hline
\end{tabular}

While the proportion is only a quarter, when it is grouped with other banks not being interested the cross-tabulation, in Table 5 (below), is $45 \%$.

Table 5. Is business banking a requirement for mortgage? Cross-tabulation

\begin{tabular}{|l|c|c|}
\hline & \multicolumn{2}{|c|}{$\begin{array}{c}\text { Other banks not } \\
\text { interested in business }\end{array}$} \\
\hline $\begin{array}{l}\text { Business banking a requirement } \\
\text { for mortgage }\end{array}$ & Yes & No \\
\hline Yes & $45 \%$ & $18.87 \%$ \\
\hline No & $55 \%$ & $81.87 \%$ \\
\hline & $100 \%$ & $100 \%$ \\
\hline
\end{tabular}

This indicates that those who are looking for mortgage funding and have difficulties finding finance are more likely to be required to bring the business under the same banking umbrella. This reveals an interesting risk management strategy on the part of those banks through deliberate non-diversification. Interestingly, when the question of how carefully costs are compared it is this group that is required to bring their business banking in order to get a residential mortgage that indicates the highest percentage of cost scrutinisers.

Advertising has little influence on the choice of the bank (Table 6, below). This is an interesting finding given the conduct of the banks in promoting themselves to businesses. If there is very limited movement between banks, then the promotion is presumably geared toward prospective start-ups. Given the considerable churn in small businesses with over $50 \%$ ceasing to be in business within 5 years, there is a large market for new accounts. However, given the responses above concerning reasons for choice and recommendations, it suggests that the advertising may not be well directed.

Table 6. Did a bank's advertising cause you to change from another bank?

\begin{tabular}{|l|c|}
\hline & Percentage \\
\hline Yes & 4 \\
\hline No & 96 \\
\hline
\end{tabular}

Bank location is potentially a key variable. Significant bank branch closures occurred through the 1990s with the introduction of technology, including automated teller machines (ATMs) and online banking. However, this pattern has reversed with new branches opening (Boulanouar, 2013). The establishment of Kiwi bank, run through Post Shops countrywide, has put pressure on the main retail banks. The close relationship between retail banking and small business banking, mooted in the literature, suggests that branch proximity is potentially an important issue.

Table 7 (below) shows that $18 \%$ of respondents think the proximity of the nearest bank branch is very important, $41 \%$ think it is 'sort of' important and $41 \%$ do not think it is important. This is predictable given that online banking facilities are now standard for day to day banking needs and internet banking has time advantages for SMEs. Generally, most major banks have good structures in setting up branches in different areas whether in a city or small town.

Table 7. How important was proximity of the nearest branch of bank to your business?

\begin{tabular}{|l|c|}
\hline & Percentage \\
\hline Not really & $40.79 \%$ \\
\hline Sort of & $40.79 \%$ \\
\hline Very & $18.42 \%$ \\
\hline
\end{tabular}

Further analysis indicates that years in business, size and industry influence the relative importance of proximity to bank branches. When businesses commence trading, they may consider whether specific banks have branches in their area. As the businesses develop, more attention may be focussed on their bank's service and so the proximity of branch may become less important.

Our results, in Table 8 (below), suggest that the presence of a customer relationship manager greatly enhances the likelihood of a long-term association with the bank, as $37 \%$ of the respondents that had customer relationship managers had been with their particular bank for over five years, whereas only 17\% of firms had been able to sustain a relationship of a similar length when a customer relationship manager was not present. Looking at even longerterm relationships the trend continues with $21 \%$ of firms sustaining a relationship with their bank for over a decade when a customer relationship manager is present, whereas only $9 \%$ manage to do so without a customer relationship manager.

Table 8. Bank has the best customer relationship manager and looks like providing the best service?

\begin{tabular}{|l|c|}
\hline & Percentage \\
\hline Yes & 67.1 \\
\hline No & 32.9 \\
\hline
\end{tabular}


The next question asks about whether the business would change banks if the bank staff changed. The majority of businesses indicate "no", as seen in Table 9 (below). However, this does raise the particularly important question of whether the relationship is with that particular bank, or with the bank staff? Is it the institution and its policies or the people and their personalities that matter in such relationships?

Table 9. Would you change banks if the bank staff changed?

\begin{tabular}{|l|c|}
\hline & Percentage \\
\hline Yes & $17.11 \%$ \\
\hline No & $82.89 \%$ \\
\hline Total & $100.00 \%$ \\
\hline
\end{tabular}

The analysis indicates that in cases where the firm does not believe that their particular bank has the best customer relationship manager and best level of perceived customer service, then just over $10 \%$ will change banks if the bank staff changed. This suggests a stronger relationship with the bank as an institution and thereby a greater affinity with the bank's policies and products. However, in cases where customer service is perceived to be at a high level, this figure nearly doubles with $20 \%$ of businesses stating that they will change banks if the bank staff changes. This supports a contention that where the quality of customer service is an important consideration for small business owners they are more concerned with the actual people with whom they are dealing. Even those who chose the bank because they knew somebody who worked there indicate they are not likely to change a bank if staff alters.

The cost comparison is not a simple matter (Locke \& Boulanouar, 2009) and the survey indicates that almost half of the businesses do not really make comparisons as shown in Table 10 (below).

Table 10. How carefully did you calculate the likely charges and compare these with other banks?

\begin{tabular}{|l|c|}
\hline & Percentage \\
\hline Not really & 47.4 \\
\hline Sort of & 18.4 \\
\hline Very & 34.2 \\
\hline
\end{tabular}

However, the businesses appear to give a somewhat contradictory response when asked whether they will change banks if there are clear cost savings, as shown in Table 11 (below). In this case, almost $70 \%$ of the businesses said that they would change. When cross-tabulated with the previous question it appears that almost half of those businesses indicating they will change do not really do any cost calculations. This is compatible with the view that cost comparisons are almost impossible to make given the lack of marketing based on price competition and the generally obfuscating pricing of services used by banks, as found by Locke and Boulanouar (2009).

Table 11. Would you change banks if there were clear cost savings?

\begin{tabular}{|l|c|}
\hline & Percentage \\
\hline Yes & 68.4 \\
\hline No & 31.6 \\
\hline
\end{tabular}

A cross-tabulation of questions 6 and 12 reveals that for those who choose "other" for the reason they selected a particular bank less than 25\% report that they consider the cost of services very carefully. In part, this may be attributable to the difficulty that Stephanou and Rodriguez (2008) observe concerning the limitations of SME management.

Information asymmetry may explain some, if not all, of the reason that $31 \%$ of SMEs stay with their bank even if other banks can provide clear cost savings. Almost a third of those SMEs surveyed stay with the same bank even when not completely satisfied with the quality of service and loan facilities provided by their current bank. Sharpe (1990) asserts that it is information asymmetry that restrains an SME from changing to another bank and proposes that SMEs stay with the same bank not simply because the bank treats them particularly well, but because high-quality firms are, in a sense, 'informationally captured'. Howorth et al. (2003) explain this 'captivity' as the inability to switch banks due to the difficulties they face in conveying accurate information about their performance to the new bank.

The underlying reason why SMEs are reluctant to change may be due to the structure of the SME. As BusinessNZ (2019) observes, the owner is often the only person available to take responsibility for banking decisions. This means they are not willing to put effort into searching and evaluating potential new banks unless they really, really have to do so. Moreover, even if the owner considers switching banks, it is difficult for them to do so due to their lack of administrative skills. Thus, banks not only have to prove they can offer an SME clear cost savings, it is also their burden to motivate the owner to change.

\subsection{Cluster analysis}

\subsubsection{Selection of variables for the cluster analysis}

Using the items measuring the importance of influence on the choice of the business-banking partner, we construct three variables. These variables and their compositions, as per Table 12, below, are used to cluster, profile and analyze this research sample.

When running cluster analysis, the treatment of missing values is very delicate as it can cause severe problems. In this study, following Kessel, Ringle, and Sarstedt (2010), we delete all the responses containing missing values and consequently our sample is reduced from 59 respondents to 52.

Table 12. Clustering variables and their composites

\begin{tabular}{|l|c|}
\hline \multicolumn{1}{|c|}{ Items } & $\begin{array}{c}\text { Variables } \\
\text { influencing the } \\
\text { choice }\end{array}$ \\
\hline Prior personal banking experience & $\begin{array}{c}\text { Experience with } \\
\text { the bank }\end{array}$ \\
\cline { 1 - 1 } $\begin{array}{l}\text { Family use of this bank } \\
\text { bank }\end{array}$ & \multirow{2}{*}{$\begin{array}{c}\text { Recommendations someone who worked in the } \\
\text { by others } \\
\text { Accountant advised you to use this }\end{array}$} \\
\cline { 1 - 1 } $\begin{array}{l}\text { Mortgage broker advised you to use this } \\
\text { bank }\end{array}$ & \\
\cline { 1 - 1 } $\begin{array}{l}\text { Insurance advisor recommended you } \\
\text { use this bank }\end{array}$ & \multirow{2}{*}{ Bank marketing } \\
\cline { 1 - 1 } The banks own advertising & \\
\cline { 1 - 1 } $\begin{array}{l}\text { Reading some publications, pamphlets, } \\
\text { and so on by the local chamber of } \\
\text { commerce, Ministry of Economic } \\
\text { Development, etc. }\end{array}$ & \\
\hline
\end{tabular}




\subsubsection{Hierarchical analysis and outliers'detection}

Outliers can affect cluster analysis, as they are not representative of the general population (Hair, Anderson, Tatham, \& Black, 1998; Hair, Sarstedt,
Matthews, \& Ringle, 2016). To identify outliers in the data, we use a Dendrogram as per Ward's approach (please see Figure 2, below). The Dendrogram does not show any outliers, such as one respondent representing one group.

Figure 2. Dendrogram as per Ward's approach

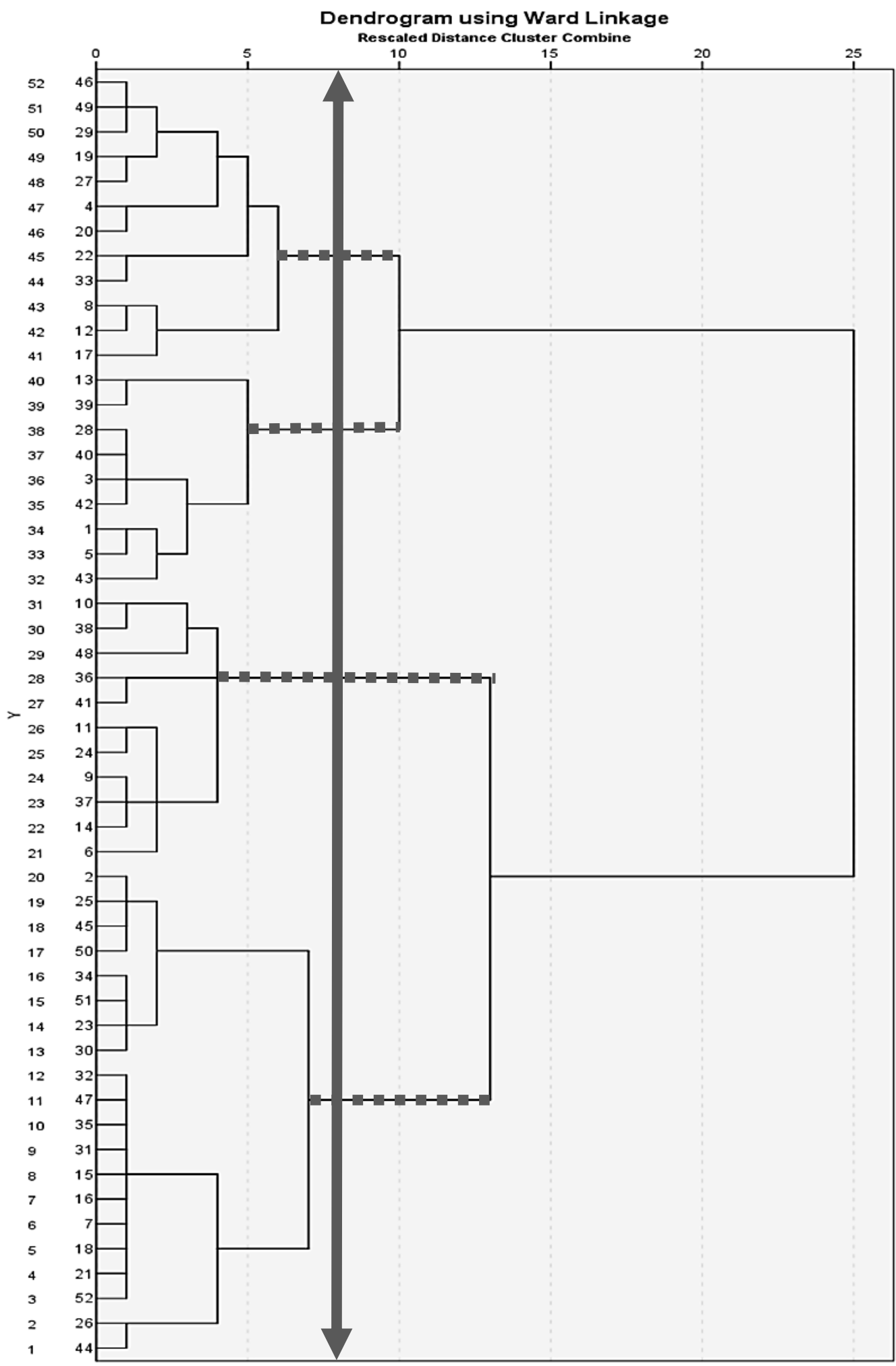

Note: ㅁ | | | means "groups retained" 
At the level of distance of 7 , we obtain 4 groups distributed as follows (please see Table 13, below). The number of individuals per group is more or less evenly distributed.

Table 13. Frequencies using Ward's method

\begin{tabular}{|l|c|c|c|c|c|}
\hline & \multicolumn{4}{|c|}{ Groups } & \multirow{2}{*}{ Total } \\
\cline { 2 - 5 } & 1 & 2 & 3 & 4 & \\
\hline Frequencies & 9 & 20 & 12 & 11 & 52 \\
\hline Percentage \% & 17.3 & 38.5 & 23.1 & 21.2 & $100 \%$ \\
\hline
\end{tabular}

\subsubsection{Profiling analysis interpretation of the clusters}

In the next section, we will try to analyze the groups' profiles by the first conducting clustering variables' mean values (please see Table 14 below).

Table 14. Clustering variables mean values

\begin{tabular}{|l|c|c|c|c|c|c|c|c|}
\hline \multirow{2}{*}{ Number } & \multirow{2}{*}{ Items } & \multicolumn{3}{|c|}{ Groups } & \multirow{2}{*}{ Mean } & \multirow{2}{*}{ F } & \multirow{2}{*}{ Sig. } \\
\cline { 3 - 8 } & & $\mathbf{1}$ & $\mathbf{2}$ & $\mathbf{3}$ & $\mathbf{4}$ & & \\
\hline 1 & Personal experience & 2.11 & 1.40 & 4.67 & 1.64 & 2.33 & 33.022 & .000 \\
\hline 2 & Family use & 4.89 & 1.75 & 4.17 & 2.09 & 2.92 & 25.639 & .000 \\
\hline 3 & Knowing staff & 5.00 & 3.85 & 4.42 & 3.60 & 4.14 & 2.449 & .075 \\
\hline 4 & Accountant recommendations & 3.78 & 5.00 & 4.83 & 3.00 & 4.30 & 13.708 & .000 \\
\hline 5 & Broker recommendations & 4.75 & 5.00 & 4.08 & 4.00 & 4.54 & 3.826 & .016 \\
\hline 6 & Insurance advisor recommendations & 4.78 & 4.61 & 5.00 & 4.22 & 4.67 & 1.755 & .170 \\
\hline 7 & Advertising & 5.00 & 5.00 & 4.09 & 3.36 & 4.44 & 9.361 & .000 \\
\hline 8 & Publications & 3.78 & 5.00 & 4.91 & 3.10 & 4.35 & 10.016 & .000 \\
\hline
\end{tabular}

Examining the four clusters and their characteristics, we notice there are significant differences between them, at the level of all the items except two, which are choice influenced by bank staff and by insurance advisor. These two items are rated highly which indicates that respondents believe these variables do not significantly influence their banking choice. However, the univariate $F$-ratio shows that all four clusters have significant differences for the first and second items (i.e., personal experience and family use).

Table 15. Clustering variable profiles

\begin{tabular}{|c|c|c|c|c|}
\hline \multirow{2}{*}{ Items } & \multicolumn{4}{|c|}{ Groups } \\
\hline & 1 & 2 & 3 & 4 \\
\hline Personal experience & Yes & Yes & No & Yes \\
\hline Family use & No & Almost yes & No & Almost yes \\
\hline Knowing staff & No & No & No & No \\
\hline Accountant recommendations & No & No & No & Neither this nor that \\
\hline Broker recommendations & No & No & No & No \\
\hline $\begin{array}{l}\text { Insurance advisor } \\
\text { recommendations }\end{array}$ & No & No & No & No \\
\hline Advertising & No & No & No & Neither this nor that \\
\hline Publications & No & No & No & Neither this nor that \\
\hline
\end{tabular}

We perform further analysis in order to more clearly profile the four clusters and their characteristics. For this, we use the one-way ANOVA to test the differences between clusters, and since we have 4 clusters, a Scheffe post hoc test is used (Hair et al., 1998; 2016). Table 15, above, shows the resultant four groups.

- The first group, labeled Confident, seem to believe that only personal experience affected their banking choice. This implies also that this group is not open to external influences, including the family's influence.

- $\quad$ The group labeled Realistic, while influenced by personal experience, is also affected by social norms. Family influence or recommendations flowing out of family use of the bank affect the decision to choose a specific banking partner.

- We label the third group Mysterious. This is because none of the study variables seem to have affected their decision regarding their primary business-banking partner. This might mean that other variables are at play and future research should consider these other variables.

- Finally, the fourth group, labeled Hesitator, does not confirm the effects of any of the suggested variables in its choice of banking partner.
The overall results from the one-way ANOVA analysis seem to suggest that the experiences lived personally by the SME owners/managers and by those close to them are the most influential factors in choosing a business-banking partner.

Figure 3. Clustering variables

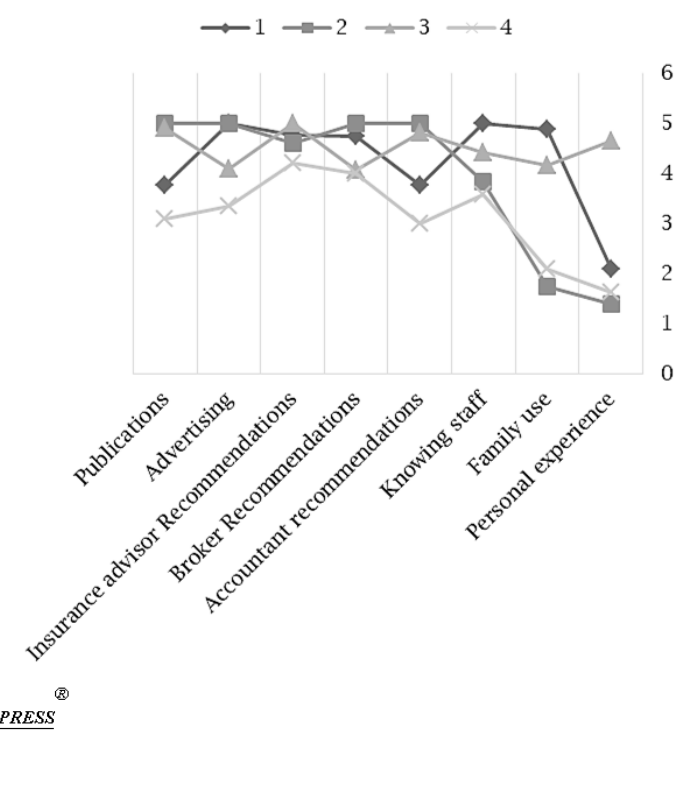




\subsubsection{Further profiling analysis of the four clusters}

For further profiling of the four clusters, we tried, in this second step, to analyze their characteristics by testing for any significant differences that may exist between them in terms of the other five items/factors reported in the literature underpinning small business' choice of a banking partner. These items are listed in Table 16, below.

Table 16. Test for significant differences

\begin{tabular}{|c|c|c|c|c|c|c|c|}
\hline \multirow{2}{*}{ Items } & \multicolumn{4}{|c|}{ Groups } & \multirow{2}{*}{ Mean } & \multirow[b]{2}{*}{$\boldsymbol{F}$} & \multirow{2}{*}{ Sig. } \\
\hline & 1 & 2 & 3 & 4 & & & \\
\hline Other banks were not interested in you. & 4.34 & 4.55 & 3.76 & 3.54 & 4.12 & 2.049 & .120 \\
\hline $\begin{array}{l}\text { The bank looked like it would provide the best } \\
\text { service. }\end{array}$ & 2.55 & 2.67 & 2.75 & 2.18 & 2.56 & 0.299 & .826 \\
\hline $\begin{array}{l}\text { The bank has the best customer relationship } \\
\text { manager. }\end{array}$ & 3.11 & 2.98 & 2.75 & 2.18 & 2.78 & 0.757 & .524 \\
\hline $\begin{array}{l}\text { How carefully did you calculate the likely charges } \\
\text { and compare these with other banks? }\end{array}$ & 3.00 & 3.75 & 3.08 & 2.36 & 3.17 & 2.159 & .105 \\
\hline $\begin{array}{l}\text { How important was proximity of the nearest branch } \\
\text { of bank to your business? }\end{array}$ & 3.36 & 3.16 & 3.83 & 2.63 & 3.24 & 1.349 & .270 \\
\hline
\end{tabular}

The results show clearly that there are no significant differences between the four clusters. For example with item 1, measuring how other banks were (not) interested in their businesses, all of the four groups confirmed that banks were interested. In addition, results for item 2 show the very close scores for all four clusters oscillating around the mean score of 2.56 .

Table 17. Correlation between the three variables used to form the four clusters

\begin{tabular}{|c|c|c|c|c|}
\hline & & Experiences & Recommendations & Marketing \\
\hline \multirow{2}{*}{ Experiences } & Pearson correlation & 1 & -0.038 & -0.103 \\
\hline & Sig. & & 0.790 & 0.468 \\
\hline \multirow{2}{*}{ Recommendations } & Pearson correlation & -0.038 & 1 & $0.344^{*}$ \\
\hline & Sig. & 0.790 & & 0.012 \\
\hline \multirow{2}{*}{ Marketing } & Pearson correlation & -0.103 & 0.344 & 1 \\
\hline & Sig. & 0.468 & 0.012 & \\
\hline
\end{tabular}

Note: * correlation is significant at the 0.05

The results from the correlation analysis (please Table 17, above) show that only recommendations by external advisors (accountants and mortgage brokers, in particular) and banks advertisement are moderately and positively correlated $($ Corr $=0.344$; Sig. $=0.012)$. Practically, this might demonstrate the role of word-of-mouth, which could be correlated with the recommendations of specialists. Bank promotion is not aimed solely at potential SB owners/managers. It is also aimed at SB advisors who recommend banks to those potential customers.

Overall, the cluster analysis results reinforce our earlier results that, consistent with other financial decisions, choosing a business-banking partner is also influenced by behavioral variables.

\section{CONCLUSION}

The traditional literature concerning the choice of the bank(s) by small businesses posits a number of possible factors as being primary considerations in the decision calculus. In this study, we add to these variables, behavioural factors, and we use them in a questionnaire for small businesses in New Zealand.

The findings indicate that behavioural factors including prior personal experience with a bank (which informs SB owner/managers attitudes), a recommendation from family, friends or associates (subjective norms), and personal contacts through knowing someone in a bank, are the most important explanatory variables regarding bank choice. Further, once associated with a bank there is very considerable inertia on the part of small businesses when it comes to making changes.

The clear-cut evidence about the weight and role of behavioural factors versus economic variables in explaining and influencing SB owners/managers selection of banking partners is to do with the cost of banking as a selection factor. Fiscal prudence is reflected in comments about differences in the cost of banking with this being a very important factor influencing a decision to move as per the traditional literature. However, when considered in the light that most SBs do not move, and most SBs did not evaluate the cost in their initial bank choice decision, it seems that it more a case of dream-time realism. The difficulty in determining the cost of banking, the search costs and the change costs are such as to largely ensure inertia. Banks, having captured a client, probably don't need to do a lot to keep them.

Our paper contributes to the theoretical/empirical work on the uniqueness of the SB sector (Ang, 1991) and is expected to aid private and government agencies involved with SBs finance to develop better policies. When developing policies and mechanisms to support SBs, policymakers should know how the personal characteristics (attitudes, perceived norms, and perceived control) of these SB decision-makers impact on their development. Subsequently, our study would empower all SB stakeholders to design programmes tailored to the specific needs of SB owner-managers.

With the evidence from our paper and other behavioural studies, future studies on financial decision making must consider behavioural factors.

The results from our investigation are based on a New Zealand sample of SME owner-managers. Thus, this paper's findings are not necessarily generalisable to other contexts. Validation of this study's results would require more studies in other geographical areas and, additionally, with crosscultural samples. Another limitation of our study which can be subject to future research is as follows: research exploring the effect(s) of demographic factors of SB owner-managers alone on their behavioural intention to select a specific banking partner. 


\section{REFERENCES}

1. Ajzen, I. (1991). The theory of planned behaviour. Organizational Behavior and Human Decision Processes, 50(2), 179-211. https://doi.org/10.1016/0749-5978(91)90020-T

2. Ajzen, I. (2002). Residual effects of past on later behavior: Habituation and reasoned action perspectives. Personality and Social Psychology Review, 6(2), 107-122. https://doi.org/10.1207/S15327957PSPR0602_02

3. Ajzen, I. (2011). The theory of planned behaviour: Reactions and reflections. Psychology \& Health, 26(9), 11131127. https://doi.org/10.1080/08870446.2011.613995

4. Al Balushi, Y, Locke, S., \& Boulanouar, Z. (2018). Islamic financial decision-making among SMEs in the Sultanate of Oman: An adaption of the theory of planned behaviour. Journal of Behavioral and Experimental Finance, 20, 30-38. https://doi.org/10.1016/j.jbef.2018.06.001

5. Alleyne, P., \& Broome, T. (2011). Using the theory of planned behaviour and risk propensity to measure investment intentions among future investors. Journal of Eastern Caribbean Studies, 36(1), 1-20. Retrieved from https://www.academia.edu/3623509/Using_the_Theory_of_Planned_Behaviour_and_Risk_Propensity_to_Measur e_Investment_Intentions_among_Future

6. Anderson, A. R., Jack, S. L., \& Dodd, S. D. (2005). The role of family members in entrepreneurial networks: Beyond the boundaries of the family firm. Family Business Review, 18(2), 135-154. https://doi.org/10.1111/j.1741-6248.2005.00037.x

7. Ang, J. S. (1991). Small business uniqueness and the theory of financial management. The Journal of Entrepreneurial Finance, 1(1), 1-13. Retrieved from https://digitalcommons.pepperdine.edu/cgi/ viewcontent.cgi?article $=1108 \&$ context $=$ jef

8. Baker, H. K., \& Ricciardi, V. (Eds.). (2014). Investor behavior: The psychology of financial planning and investing. https://doi.org/10.1002/9781118813454

9. Bank of America. (2016, November 15). Bank of America survey finds family, friends and community core to small business success [Press release]. Retrieved from http://newsroom.bankofamerica.com/pressreleases/small-business-banking/bank-america-survey-finds-family-friends-and-community-core-sm

10. Barton, S. L., \& Gordon, P. I. (1987). Corporate strategy: Useful perspective for the study of capital structure? Academy of Management Review, 12(1), 67-75. https://doi.org/10.5465/amr.1987.4306479

11. Barton, S. L., \& Gordon, P. J. (1988). Corporate strategy and capital structure. Strategic Management Journal, 9(6), 623-632. https://doi.org/10.1002/smj.4250090608

12. Beach, L. R. (1990). Image theory: Decision making in personal and organizational contexts. Chichester, the UK: John Wiley \& Sons Inc.

13. Beattie, V., Goodacre, A., \& Thomson, S. J. (2006). Corporate financing decisions: UK survey evidence. Journal of Business Finance \& Accounting, 33(9-10), 1402-1434. https://doi.org/10.1111/j.1468-5957.2006.00640.x

14. Berger, A. N., \& Udell, G. F. (1995). Relationship lending and lines of credit in small firm finance. The Journal of Business, 68(3), 351-381. https://doi.org/10.1086/296668

15. Boulanouar, Z. (2013). An analysis of the benefits for New Zealand banks of adopting a relationship banking model for small business clients (Doctoral thesis, University of Waikato). Retrieved from https://researchcommons.waikato.ac.nz/bitstream/handle/10289/7811/thesis.pdf?sequence=3\&isAllowed=y

16. Brettel, M., Breuer, W., Espel, P., \& Abedin, A. (2009). Private equity for SME: A behavioural model of the demandside perspective. https://doi.org/10.2139/ssrn.1141068

17. BusinessNZ. (2019). Speaking up for small business. Retrieved from https://www.businessnz.org.nz/businessissues/small-business

18. Carey, D., \& Flynn, A. (2005) Is bank finance the Achilles' heel of Irish SMEs? Journal of European Industrial Training, 29(9), 712-729. https://doi.org/10.1108/03090590510629849

19. Chang, E. P. C., Memili, E., Chrisman, J. J., Kellermanns, F. W., \& Chua, J. H. (2009). Family social capital, venture preparedness, and start-up decisions: A study of Hispanic entrepreneurs in New England. Family Business Review, 22(3), 279-292. https://doi.org/10.1177/0894486509332327

20. Coyle, T. (1999). The bank of tomorrow. Americans Community Banker, 8(7), 16-18.

21. Driscoll, J. (1999). Bank wars: Episode 2. The branches strike back. Bank Marketing, 31(12), 20-30.

22. East, R. (1993). Investment decisions and the theory of planned behaviour. Journal of Economic Psychology, 14(2), 337-375. https://doi.org/10.1016/0167-4870(93)90006-7

23. Farrell, L., Fry, T. R. L., \& Risse, L. (2016). The significance of financial self-efficacy in explaining women's personal finance behaviour. Journal of Economic Psychology, 54, 85-99. https://doi.org/10.1016/j.joep.2015.07.001

24. Federation of Small Businesses. (1998). Small business finance and the economy. Retrieved from FSB website: https://www.fsb.org.uk/media-centre.html

25. Fishbein, M., \& Ajzen, I. (1975). Belief, attitude, intention, and behavior: An introduction to theory and research. Retrieved from http://people.umass.edu/aizen/f\&a1975.html

26. Fishbein, M., \& Ajzen, I. (2010). Predicting and changing behavior: The reasoned action approach. https://doi.org/10.4324/9780203838020

27. Gallo, M. Á., Tàpies, J., \& Cappuyns, K. (2004). Comparison of family and nonfamily business: Financial logic and personal preferences. Family Business Review, 17(4), 303-318. https://doi.org/10.1111/j.17416248.2004.00020.x

28. Ghosh, P., Ghosh, S., \& Khan, L. (2015). Current trend of bank selection criteria of retail customers in Bangladesh: An investigation. Global Business \& Finance Review, 20(2), 27-34. https://doi.org/10.17549/gbfr.2015.20.2.27

29. Ghoui, A., Khan, N., \& Kareem, O. A. (2016). Improving employees behavior through extension in theory of planned behavior: A theoretical perspective for SMEs. International Journal of Business and Management, 11(11), 196-213. https://doi.org/10.5539/ijbm.v11n11p196

30. Gibcus, P., Vermeulen, P. A. M., \& De Jong, J. P. J. (2006). Strategic decision-making in small firms: Towards a taxonomy of entrepreneurial decision-makers. Retrieved from https://www.researchgate.net/publication/ 5012690_Strategic_Decision-Making_in_Small_Firms_Towards_a_Typology_of_Entrepreneurial_Decision-Makers

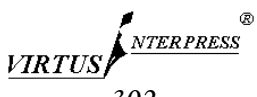


31. Greve, A., \& Salaff, J. W. (2003). Social networks and entrepreneurship. Entrepreneurship Theory Practice. 28(1), 1-22. https://doi.org/10.1111/1540-8520.00029

32. Hair, J. F, Anderson, R. E., Tatham, R. L., \& Black, W. C. (1998). Multivariate data analysis (5th ed.). Upper Saddle River, NJ, the USA: Prentice Hall.

33. Hair, J. F., Jr., Sarstedt, M., Matthews, L. M., \& Ringle, C. M. (2016). Identifying and treating unobserved heterogeneity with FIMIX-PLS: Part I - method. European Business Review, 28(1), 63-76. https://doi.org/10.1108/EBR-09-2015-0094

34. Heck, R. K. Z. (2004). A commentary on "entrepreneurship in family vs. non-family firms: A resource-based analysis of the effect of organizational culture." Entrepreneurship Theory and Practice, 28(4), 383-389. https://doi.org/10.1111/j.1540-6520.2004.00052.x

35. Heffernan, S. (2006). UK bank services for small business: How competitive is the market? Journal of Banking \& Finance, 30(11), 3087-3110. https://doi.org/10.1016/j.jbankfin.2006.05.002

36. Holstius, K., \& Kaynak, E. (1995). Retail banking in Nordic countries: The case of Finland. International Journal of Bank Marketing, 13(8), 10-20. https://doi.org/10.1108/02652329510098873

37. Howorth, C., Peel, M. J., \& Wilson, N. (2003). An examination of the factors associated with bank switching in the U.K. small firm sector. Small Business Economics, 20, 305-317. https://doi.org/10.1023/A:1022963226621

38. Julian, C. C., \& Ramaseshan, B. (1994). The role of customer-contact personnel in the marketing of a retail bank's services. International Journal of Retail \& Distribution Management, 22(5), 29-34. https://doi.org/10.1108/09590559410067316

39. Kahneman, D., \& Tversky, A. (1979). Prospect theory: An analysis of decision under risk. Econometrica, 47(2), 263-292. https://doi.org/10.2307/1914185

40. Kaur, M. (2015). Bank selection process and market segmentation: Evidence from Indian exporting SMEs. Vision: The Journal of Business Perspective, 19(2), 79-88. https://doi.org/10.1177/0972262915575650

41. Kelley, S. J., \& Buultjens, J. (2003). Venture capital in regional Australia: Attitudes toward venture capital requirements among SME principals and their advisors. Australasian Journal of Business \& Social Inquiry, 1(1), 30-42. Retrieved from https://pdfs.semanticscholar.org/0878/45e28ef4a067ca9f611645f0e23ef73162b0.pdf

42. Kessel, F., Ringle, C. M., \& Sarstedt, M. (2010). On the impact of missing values on model selection in FIMIX-PLS. Proceedings of the 2010 INFORMS Marketing Science Conference.

43. Koropp, C., Kellermanns, F. W., Grichnik, D., \& Stanley, L. (2014). Financial decision making in family firms: An adaptation of the theory of planned behavior. Family Business Review, 27(4), 307-327. https://doi.org/10.1177/0894486514522483

44. Locke, S., \& Boulanouar, Z. (2009). Cost of small business banking: A New Zealand study. Service Business, 3, 211-227. https://doi.org/10.1007/s11628-008-0057-z

45. López Salazar, A., Contreras Soto, R., \& Espinosa Mosqueda, R. (2012). The impact of financial decisions and strategy on small business competitiveness. Global Journal of Business Research, 6(2), 93-103. Retrieved from https://www.researchgate.net/profile/Contreras_Soto/publication/228241675_The_Impact_of_Financial_Decisi ons_and_Strategy_on_Small_Business_Competitiveness/links/Ofcfd50a78f05124b1000000/The-Impact-ofFinancial-Decisions-and-Strategy-on-Small-Business-Competitiveness.pdf

46. López-Gracia, J., \& Sánchez-Andújar, S. (2007). Financial structure of the family business: Evidence from a group of small Spanish firms. Family Business Review, 20(4), 269-287. https://doi.org/10.1111/j.17416248.2007.00094.x

47. López-Gracia, J., \& Sogorb-Mira, F. (2008). Testing trade-off and pecking order theories financing SMEs. Small Business Economics, 31, 117-136. https://doi.org/10.1007/s11187-007-9088-4

48. Lucey, A. J. (1990). What bank services do small businesses want? Commercial Lending Review, 5(3), 92-94.

49. Lymperopoulos, C., Chaniotakis, I. E., \& Soureli, M. (2006). The importance of service quality in bank selection for mortgage loans. Managing Service Quality: An International Journal, 16(4), 365-379. https://doi.org/10.1108/09604520610675702

50. Matthews, C. H., Vasudevan, D. P., Barton, S. L., \& Apana, R. (1994). Capital structure decision making in privately held firms: Beyond the finance paradigm. Family Business Review, 7(4), 349-367. https://doi.org/10.1111/j.1741-6248.1994.00349.x

51. Mazur, M. (2007). Bank products lack differentiation in eyes of small business owners. Community Banker (Washington), 16(5).

52. Michaelas, N., Chittenden, F., \& Poutziouris, P. (1998). A model of capital structure decision making in small firms. Journal of Small Business and Enterprise Development, 5(3), 246-260. https://doi.org/10.1108/EUM0000000006786

53. Ministry of Business, Innovation, and Employment. (2017). Small businesses in New Zealand: How do they compare with larger firms? Retrieved from https://www.beehive.govt.nz/sites/default/files/201712/Small\%20Business\%20-\%20Annex\%203\%20Small\%20Business\%20Factsheet.pdf

54. Moritz, A., Block, J. H., \& Heinz, A. (2016). Financing patterns of European SMEs - an empirical taxonomy. Venture Capital, 18(2), 115-148. https://doi.org/10.1080/13691066.2016.1145900

55. Myers, S. C. (1984). The capital structure puzzle. The Journal of Finance, 39(3), 574-592. https://doi.org/10.1111/j.1540-6261.1984.tb03646.x

56. Mylonakis, J. (2008). The influence of banking advertising on bank customers: An examination of Greek bank customers' choices. Banks and Bank Systems, 3(4), 44-49. Retrieved from https://businessperspectives.org/journals/banks-and-bank-systems/issue-156/the-influence-of-bankingadvertising-on-bank-customers-an-examination-of-greek-bank-customers-choices

57. Mylonakis, J., Malliaris, P. G., \& Siomkos, G. J. (1998). Marketing-driven factors influencing savers in the Hellenic bank market. Journal of Applied Business Research, 14(2), 109-116. https://doi.org/10.19030/jabr.v14i2.5719

58. Nielsen, J. F., Terry, C., \& Trayler, R. M. (1998). Business banking in Australia: A comparison of expectations. International Journal of Bank Marketing, 16(6), 253-263. https://doi.org/10.1108/02652329810241393

59. Nielsen, J. F., Trayler, R. M., \& Brown, B. M. (1995). Banking expectations: Do bankers really understand the needs of the small business customer? The Journal of Entrepreneurial Finance, 4(2), 99-112. Retrieved from https://digitalcommons.pepperdine.edu/jef/vol4/iss2/1/ 
60. Norton, E. (1991). Capital structure and small public firms. Journal of Business Venturing, 6(4), 287-303. https://doi.org/10.1016/0883-9026(91)90020-E

61. Pauluzzo, R., \& Geretto, E. F. (2017). Evaluating customers' behavioral intentions in less significant financial institutions. International Journal of Bank Marketing, 35(4), 714-732. https://doi.org/10.1108/IJBM-06-20160078

62. Pearson, A. W., Carr, J. C., \& Shaw, J. C. (2008). Toward a theory of familiness: A social capital perspective. Entrepreneurship Theory and Practice, 32(6), 949-969. https://doi.org/10.1111/j.1540-6520.2008.00265.x

63. Perry, M., Cardow, A., Massey, C., \& Tweed, D. (2006). Telling tales: A report on New Zealand SMEs \& their relationships with banks \& accountants (New Zealand Centre for SME Research, Massey University). Retrieved from https://www.massey.ac.nz/massey/fms/sme/businessmeasure/Summary_ReportBanks_FINAL.pdf

64. Rauch, J. H., \& Hendrickson, J. M. (2004) Does bank consolidation hurt the small business borrower? Small Business Economics, 23, 219-226. https://doi.org/10.1023/B:SBEJ.0000032030.01961.ce

65. Read, L. H. (2002). The financing of small business: A comparative study of male and female small business owners. https://doi.org/10.4324/9780203024942

66. Romano, C. A., Tanewski, G. A., \& Smyrnios, K. X. (2001). Capital structure decision making: A model for family business. Journal of Business Venturing, 16(3), 285-310. https://doi.org/10.1016/S0883-9026(99)00053-1

67. Schoemaker, P. J. H. (1982). The expected utility model: Its variants, purposes, evidence and limitations. Journal of Economic Literature, 20, 529-563. Retrieved from https://www.researchgate.net/profile/Paul_Schoemaker/ publication/4721197_The_Expected_Utility_Model_Its_Variants_Purposes_Evidence_and_Limitations/links/0c96 05325c1417b1e2000000.pdf

68. Scott, J., \& Dunkelberg, B. (2006). Convenient location most important bank characteristic according to smallbusiness owners. Business Credit, 108(8), 41.

69. Sharpe, S. A. (1990). Asymmetric information, bank lending and implicit contracts: A stylized model of customer relationships. The Journal of Finance, 45(4), 1069-1087. https://doi.org/10.2307/2328715

70. Sondari, M. C., \& Sudarsono, R. (2015). Using theory of planned behavior in predicting intention to invest: Case of Indonesia. International Academic Research Journal of Business and Technology, 1(2), 137-141. Retrieved from http://www.iarjournal.com/wp-content/uploads/IBTC2015-p137-141.pdf

71. Southey, G. (2011). The theories of reasoned action and planned behaviour applied to business decisions: A selective annotated bibliography. Journal of New Business Ideas \& Trends, 9(1), 43-50. Retrieved from http://jnbit.org/upload/JNBIT_Southey_2011_1.pdf

72. Stephanou, C, \& Rodriguez, C. (2008). Bank financing to small and medium-sized enterprises (SMEs) in Colombia (World Bank Policy Research Working Paper No. 4481). https://doi.org/10.1596/1813-9450-4481

73. Strachan, P. E., \& Weston, J. P. (1998). Small business lending and the changing structure of the banking industry. Journal of Banking and Finance, 22(6-8), 821-845. https://doi.org/10.1016/S0378-4266(98)00010-7

74. Taylor, S., \& Todd, P. (1995). Decomposition and crossover effects in the theory of planned behavior: A study of consumer adoption intentions. International Journal of Research in Marketing, 12(2), 137-155. https://doi.org/10.1016/0167-8116(94)00019-K

75. Thaler, R. H. (1999). Mental accounting matters. Journal of Behavioral Decision Making, 12(3), 183-206. https://doi.org/10.1002/(SICI)1099-0771(199909)12:3\%3C183::AID-BDM318\%3E3.0.CO;2-F

76. The Economist. (2007, June 14). Finance and economics: Branching out. Retrieved from https://www.economist.com/finance-and-economics/2007/06/14/branching-out

77. Thompson, K. E., \& Panayiotopoulos, P. (1999). Predicting behavioural intention in a small business context. Journal of Marketing Practice: Applied Marketing Science, 59 5), https://doi.org/10.1108/EUM0000000004564

78. Trayler, R., Nielson, J., \& Jones, R. (2000). How small business firms select a bank: Comparisons between the United States and Australia. Journal of Financial Services Marketing, 5, 73-85. https://doi.org/10.1057/palgrave.fsm.4770008

79. Venkatesh, V., \& Davis, F. D. (2000). A theoretical extension of the technology acceptance model: Four longitudinal field studies. Management Science, 46(2), 186-204.

80. Wiklund, J., Delmar, F., \& Sjöberg, K. (2005). Entrepreneurship at any expense? The effect of human capital on high-potential entrepreneurship. In Frontiers of Entrepreneurship Research: Proceedings of the 25th Annual Entrepreneurship Research Conference, Babson College (pp. 109-123).

81. Yue, H., \& Tom, G. (1995). How the Chinese select their banks. Journal of Retail Banking, 16(4).

82. Zellweger, T. M., Frey, U., \& Halter, F. A. (2005). A behavioral perspective to financing decisions in family and nonfamily firms. Retrieved from https://pdfs.semanticscholar.org/5ada/ 616da2fec349daa502fbd3e0c518f8ca0bfb.pdf 


\section{APPENDIX}

\section{List of survey questions}

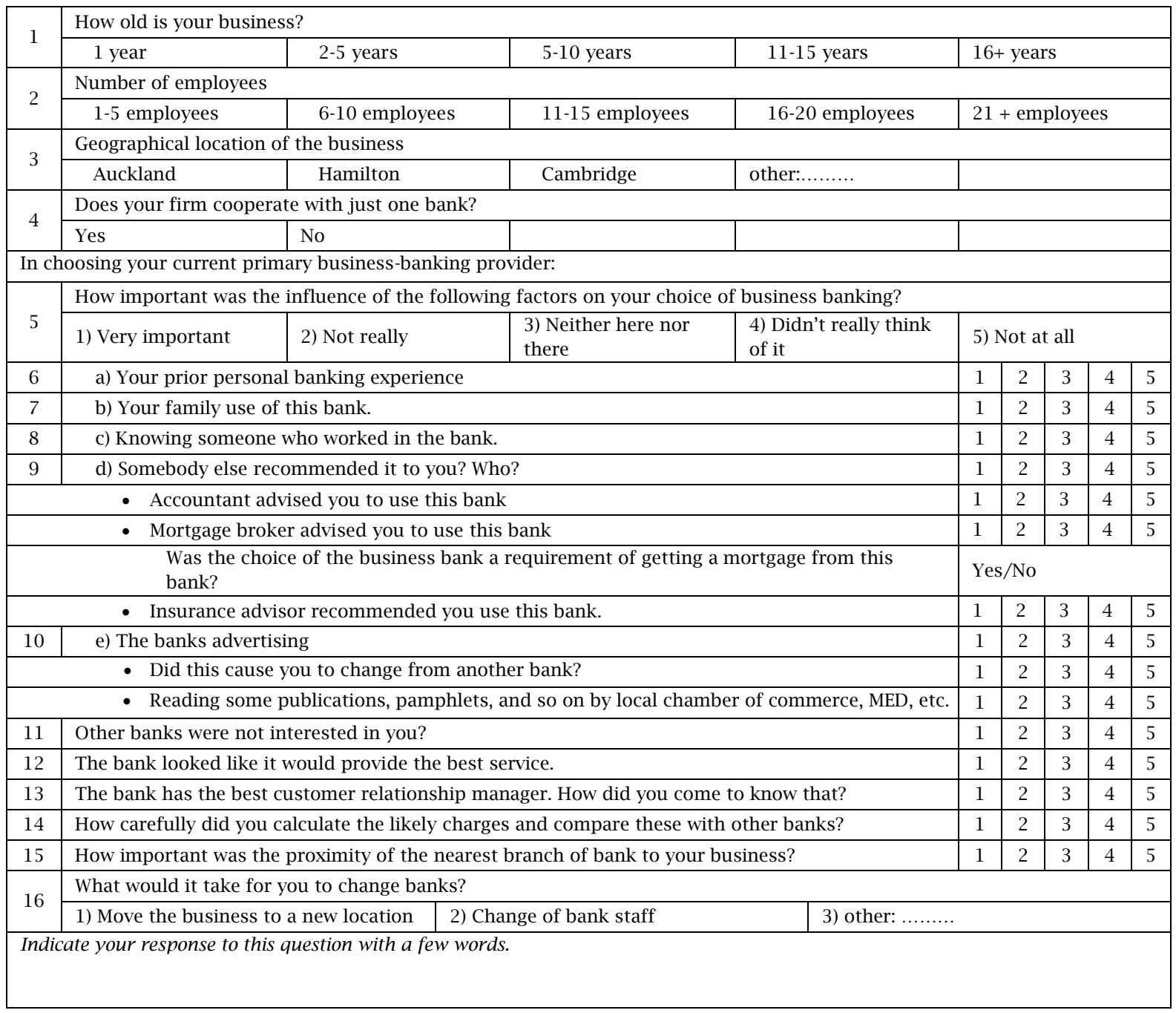

